\title{
The Indian Ocean of Law: Hybridity and Space
}

MAHMOOD KOORIA and SANNERAVENSBERGEN

A sixteenth-century Arabic legal text entitled Tuhfat al-Muhtāj, by Ibn Ḥajar al-Haytamī, travelled from the Middle East to South Asia, East Africa, and Southeast Asia. It was used in Muslim legal circles as well as in the colonial courts of British India, Zanzibar, and the Dutch East Indies. It was translated into Javanese (Kitab Toehpah), then retranslated into Dutch and interpreted by some colonial lawyers as a legal code of Javanese origin. While the Tuhfa was taught in traditional religious institutions, Kitab Toehpah was taught at Leiden University for future colonial officials studying the Javanese language and culture, who referred to it as the Corpus Juris Javanum. ${ }^{1}$ The journey of the Tuhfa is only one example of first, how legal ideas and texts travelled across geographical and chronological borders and second, how these ideas shaped the legal traditions and systems they encountered during their mobility. These moments of interaction reveal how legal cultures negotiated, influenced, and conflicted with one other.

The Indian Ocean functioned as a maritime highway that connected different cultures, societies, and religions over centuries. In the oceanic realm, law flowed through the circulation of people, ideas, texts, ships, and goods. Those were not exclusive and autonomous entities: they coexisted, conflicted, and were inevitably hybrid in themselves. European codes and Islamic kitabs, qadis in Oman or Zanzibar, penghulus in Java, investigation committees in Bengal, school councils in Ceylon, and ships in Mauritius got intertwined in recurring webs of law. Law shaped and was shaped by these hybridities on the large oceanic canvas, with many micro-sites varying from ports to courts.

The mobility of law across the Indian Ocean world is a relatively new field of research. Recent studies have increasingly addressed the cultural mechanisms of law both within and beyond imperial and colonial structures during the early modern and modern periods. Lauren Benton firmly placed legal pluralism on the agenda of historical research about empires. ${ }^{2}$ In Legal Pluralism and Empires: 1500-1850, Benton and Richard Ross brought legal practices to the centre of discussions about imperial expansions. ${ }^{3}$ Paul Halliday proposed using "legal pluralities" in such contexts, against the age-old frameworks of legal pluralism. ${ }^{4}$ In an Indian Ocean context, specifically with regard to the British Empire, various contributors to the special issue 
"The Travels of Law: Indian Ocean Itineraries" in Law and History Review, evaluated the imperativeness of law in establishing British hegemony across maritime worlds. $^{5}$ In a synthesising afterword to that collection, Engseng Ho maps out how and why we should analyse legal mobilities of the Indian Ocean through thick transregionalism and disaggregation. ${ }^{6}$ This research-without claiming to be a complete overview of all the relevant publications in this field-has been vital in understanding the importance and significance of law in the Indian Ocean.

The international conference "Ocean of Law: Intermixed Legal Systems Across the Indian Ocean World, 1550-1950," held at Leiden University in 2015, intended to continue these investigations across the borders of empires, regions, periods, and states, and to contribute to the ongoing debate on the mobility of law and its nuances. In the background of existing historiography related to legal pluralism, movement of ideas, information networks, and cultural brokerage, the main themes of discussion were the construction of religious and secular laws, the colonial legal discourses and their reforming enterprises of non-colonial laws, and the functioning of pluralistic legal institutions and their organisation. The relationships between the theory and practice of law were also in the forefront of discussion: macro legal theories' regional applicability and micro legal practices' negotiations with the broader systems. With regard to legal texts, the exclusions and inclusions, selections and deletions in practice were also explored. Altogether, the focus of presentations and discussions was not so much on temporal developments, but rather on the spatialisation of law in the oceanic world.

In this issue, we continue the discussions focusing on spatial aspects of legal intersections in the Indian Ocean arena. We bring together different empirical studies that deal with varied legal expressions in texts, courts, ships, and communities. In this spatial context, we discuss cross-cultural encounters and translations of legal traditions that often travelled long distances - by textual genealogies or personal intermediations - and the consequences for the development of hybrids as local practices and legal pluralities. All these sites reflected and cross-culturally moulded the Indian Ocean legal realm through interactions and encounters. Looking into such features, this issue presents case studies from the thirteenth to the twentieth century, from the Cape of Good Hope to the Straits of Malacca, from Semarang to Amsterdam.

The mobility of law affected legal spheres offshore and onshore, originating from a conscious agency as well as from cross-cultural communications, either way resulting in the emergence and development of hybridity across the Indian Ocean world. The contributors to this issue focus on this mobile hybridity, in various and sometimes overlapping ways, where legal hybridity and mobile hybrids are discussed and meticulously analysed as a practice, outcome, and/or strategy.

Nathan Perl-Rosenthal and Fahad Bishara offer compelling cases that enable them to investigate the mobility, hybridity, and spatial dimensions of everyday intersections of law. Perl-Rosenthal scrutinises the pillage of the British East Indiaman Osterley in French Mauritius at the end of the eighteenth century. Mobility in this case is not only a matter of the movements of the ship, which constantly 
transferred from one legal sphere into another. It also inheres in the several legal cultures with which the criminal case intersected, both crossing legal systems (British, French, and local) and crossing different types of law, such as civil and maritime. The hybrid mobility of law is further explored by Fahad Bishara, who traces the travels of early-twentieth century mobile litigants and legal documents from both British and Islamic judges between Oman and Zanzibar, in long-lasting disputes over property. He illustrates the cognizance of landowners, qadis, and jurists of the possibilities of a mobile law and the complications of patronage regimes in the competing and multiple legalities of the Indian Ocean. He argues that the litigants" "legal imagination" of the Indian Ocean enabled them to exploit the commercial possibilities and find the gaps in the legal mosaic that crossed administrative borders.

A number of the contributors complicate the concept of hybridity by unravelling texts and institutions that came together in the process of evolving pluralities in the Indian Ocean world. Mahmood Kooria analyses how early encounters of the Dutch East India Company (VOC) with Javanese legal scholars, institutions, and texts led to a compilation of intermixed laws. He juxtaposes the Semarang Compendium (1750) with Islamic and Javanese legal texts in order to question the origins of this so-called Muhammadan law-book that the VOC officials claimed to be based on the Muharrar, presumably a text of the same title by Rāfíi (d. 1226). Far from being based on any known Islamic or Javanese legal texts, Kooria demonstrates that the Compendium is a hybrid text that the Dutch officials constructed by melding a number of different legal practices and customs. Conversely, Nadeera Rupesinghe demonstrates in the context of eighteenth-century Galle in Sri Lanka how local communities and Dutch officials forged compromises between legal orders. Looking at cases of marriage and divorce, she illustrates how the VOC officials faced a powerful institutionalised normative order and had to compromise with it against their will. The civil cases that she analyses also reveal constant negotiations in which women had agency.

The processes of developing hybrid legal regimes reveal compromises and conflicts, and it is the long trajectories of these processes, and its consequences for both local legal cultures and centralising colonial states, that are at the centre of analysis in the articles by Sanne Ravensbergen and Elizabeth Lhost. Ravensbergen questions overly-static notions of the segregated dual legal system in nineteenth-century Java by pointing to a long-standing tradition of pluralistic courts consisting of European and local actors administering justice according to a mixture of European, Islamic, Javanese, and local laws, customs, and procedures. Ravensbergen shows how colonial officials - wedged between the conflicting aims of the official policy of separate jurisdictions and the unifying ambitions of Supreme Court judges - deliberately made use of hybridity within pluralistic courts, the Landraden, as a strategy to sustain colonial power. Lhost looks at how the qadis of Bharuch responded and resisted when the British government tried to limit their functions in the early nineteenth century. The qadis attempted to convince the English East India Company to reverse these reforms, emphasising their relevance as intermediaries in increasing the Company's control. She deploys unique archives of legal registers and documents to 
demonstrate how the long-term encounters of qadis and the colonial state reconfigured local social relations.

Networks transcending the European-Asian binary are central to Byapti Sur's article, as she argues that the assumed binary was diligently upheld by contemporary European officials who applied "politics of corruption" by emphasising stereotypes of "the Asians" as being corrupt in order to emphasise their own trustworthiness. She attempts to overcome this binary by disentangling the intertwined networks of Europeans and locals by closely investigating two corruption cases in seventeenthcentury Bengal in which personal networks crossed ethnic borders and entered the legal space. Through these cases Sur presents telling examples of convergence and conflict that stood at the core of hybrid legal practice.

All these cases, from East Africa to Southeast Asia, present nuanced examinations of legal encounters where hybridity was very much apparent as a practice, outcome, and/or strategy. In addition to moving beyond static understandings of coloniser and colonised, these works suggest that cross-sectional, cross-cultural, and cross-religious encounters are at the heart of an Indian Ocean of law, not only in the early modern, but also in the modern world. Interestingly the hybrids, a product of the mobility of law, moved again within the Indian Ocean itself, and even beyond. The mobile hybrids undertook multi-directional journeys and contributed to the development of the Indian Ocean as an even more connected legal space. Investigating the ocean as a single space provides opportunities to study law beyond nation-states, empires, and similar compartmentalised structures. For the Indian Ocean, it reveals the long tradition of the mobility of law, hybridity, and mobile hybrids evolving from an unambiguously large amount of cross-culturalism. Over centuries, intermixed legal cultures evolved, creating oceans of law.

\section{Notes}

1 NA-HaNA, MvK, V. 24-9-1873 no. 7/1713; P. J. Veth, "Levensbericht T. Roorda," in Jaarboek, (1874 Amsterdam) 55.

2 Lauren A Benton. Law and Colonial Cultures: Legal Regimes in World History, 1400-1900. Cambridge and New York: Cambridge University Press, 2002; Lauren A. Benton. A Search for Sovereignty: Law and Geography in European Empires, 1400-1900. Cambridge and New York: Cambridge University Press, 2010.

3 Lauren A. Benton and Richard Ross. Legal Pluralism and Empires, 1500-1850.
New York: New York University Press, 2013.

4 Paul Halliday. "Law's Histories: Pluralisms, Pluralities, Diversity." In Benton and Ross, 261-78.

5 Renisa Mawani and Iza Hussin, "The Travels of Law: Indian Ocean Itineraries." Law and History Review 32:4 (November 2014): 733-747.

6 Engseng Ho. "Afterword: Mobile Law and Thick Transregionalism." Law and History Review 32:4 (November 2014): 883-9. 